\title{
Mcl-1 Inhibitor AZD5991
}

National Cancer Institute

\section{Source}

National Cancer Institute. Mcl-1 Inhibitor AZD5991. NCI Thesaurus. Code C137989.

An inhibitor of induced myeloid leukemia cell differentiation protein (myeloid cell leukemia-

1; Mcl-1; BCl2-L-3), with potential pro-apoptotic and antineoplastic activities. Upon administration, AZD5991 binds to $\mathrm{Mcl}-1$, thereby preventing the binding of $\mathrm{Mcl}-1$ to and inactivation of certain pro-apoptotic proteins, and promoting apoptosis of cells overexpressing $\mathrm{Mcl}-1$. Mcl-1, an anti-apoptotic protein belong ing to the $\mathrm{Bcl}-2$ family of proteins, is upregulated in cancer cells and promotes tumor cell survival. 